\title{
BEBAN KELUARGA MERAWAT LANSIA DAPAT MEMICU TINDAKAN KEKERASAN DAN PENELANTARAN TERHADAP LANSIA
}

\author{
R. Siti Maryam ${ }^{1 *}$, Rosidawati ${ }^{1}$, Ni Made Riasmini ${ }^{1}$, Eros Siti Suryati ${ }^{1}$ \\ 1. Politeknik Kesehatan Jakarta III Jurusan Keperawatan, Jakarta 13230, Indonesia \\ *Email:rdmaryam@yahoo.com
}

\begin{abstract}
Abstrak
Memberikan perawatan pada lansia dengan penyakit kronis menimbulkan perasaan strain atau burden (beban) pada caregiver (pengasuh) yang dapat mempengaruhi kualitas hidup keluarga. Penelitian ini bertujuan untuk mendapatkan gambaran tentang faktor-faktor yang berhubungan dengan beban keluarga merawat lansia. Jenis penelitian ini adalah deskriptif korelasi dengan pendekatan cross sectional menggunakan uji regresi logistik ganda. Sampel berjumlah 205 responden dengan pengambilan sampel secara gugus bertahap. Hasil penelitian menunjukkan hubungan bermakna antara usia keluarga $(\mathrm{p}=0,052 ; \alpha=0,05)$, status kesehatan $(p=0,018 ; \alpha=0,05)$, pengetahuan $(p=0,046 ; \alpha=0,05)$, dan kepuasan $(p=0,033 ; \alpha=0,05)$ dengan beban merawat lansia. Faktor yang paling berkontribusi terhadap beban merawat adalah status kesehatan keluarga $(\mathrm{OR}=2,632)$. Rekomendasi hasil penelitian yaitu gambaran tentang tingkat beban yang dialami keluarga dalam merawat lansia dapat dijadikan sebagai masukan untuk mengembangkan program pemberdayaan keluarga serta program promosi kesehatan untuk mengurangi beban merawat yang pada akhirnya dapat mengurangi tindakan kekerasan dan penelantaran.
\end{abstract}

Kata kunci: beban merawat, lansia, pemberdayaan keluarga, penelantaran, pengasuh

\begin{abstract}
Provide care to the elderly with chronic diseases induce a feeling of strain or burden on the caregiver that can affect on the quality of family life. This study aims to know the factors associated with caregiver burden for the elderly. This research is an observational research with cross-sectional approach using multiple logistic regression test. Total sample is 205 respondents which is taken by cluster multistage sampling. Significant relationship was found in the age $(p=0.052 ; \alpha=0.05)$ the health status $(p=0.018 ; \alpha=0.05)$, knowledge $(p=0.046 ; \alpha=0.05)$, and satisfaction $(p=0.033 ; \alpha=0.05)$ offamily with the burden of care. The factors that most contribute to caregiver burden is the family health status $(O R=2,632)$. A picture of the level burden experienced by families in caring for the elderly can be used as an input to develop a family empowerment and health promotion programs to reduce caregiver burden and may reduce violence and negligence.
\end{abstract}

Keywords: burden, caregiver, elderly, family empowerment, negligence

\section{Pendahuluan}

Tingginya jumlah penduduk lansia saat ini berdampak terhadap berbagai permasalahan yang dihadapi oleh lansia baik aspek sosial, ekonomi, dan kesehatan. Peningkatan jumlah penduduk lansia di Indonesia yang sangat pesat dari tahun ke tahun menimbulkan berbagai permasalahan baik aspek sosial, ekonomi, dan kesehatan. Data BPS (2005), kondisi sosial lanjut usia di Indonesia masih memprihatinkan.

Jumlah lansia terlantar sebesar 2,7 juta (15\% dari jumlah total penduduk lansia). Hal tersebut berkaitan dengan perubahan yang terjadi akibat proses menua dimana lansia mengalami penurunan pada berbagai fungsi organ tubuh yang dapat menimbulkan ketidakmampuan berfungsi secara optimal yang berdampak terhadap kualitas hidup lansia. Kondisi tersebut memerlukan dukungan dari berbagai pihak, yaitu terutama keluarga sebagai caregiver yang mampu merawat lanjut usia dan memenuhi kebutuhannya, baik secara fisik maupun psikososial. Lanjut usia yang terlantar di wilayah perkotaan di Indonesia yaitu sebesar 13,4\% yang tidak mendapatkan perawatan dari keluarga dan masyarakat.

Keluarga sebagai caregiver mempunyai peran penting karena disinilah individu dapat tumbuh dan berkembang. Keluarga merupakan sumber pendukung utama bagi lansia di masyarakat. 
Efektifitas dukungan keluarga adalah komponen kunci terhadap kesejahteraan lansia. Perawatan yang dilakukan oleh keluarga sebagai caregiver untuk lansia dikaitkan dengan stres oleh karena gangguan fungsional dan psikologis serta penyakit kronik yang dialami lansia.

Menurut Sales (2003), yang menyatakan bahwa memberi perawatan pada lansia dengan penyakit kronis menimbulkan perasaan burden atau strain pada caregiver yang dapat memberikan pengaruh terhadap kualitas hidup keluarga. Caregiver burden adalah respon multidimensi terhadap stresor fisik, psikologis, sosial, dan finansial yang dihubungkan dengan pengalaman caregiver dalam merawat klien (Kazuya, Polgar-Bailey, \& Takeuchi, 2000 dalam Etters, Goodall, \& Harrison, 2008).

Menurut Morimoto, Schreiner, dan Asano (2003) bahwa faktor-faktor yang berpengaruh terhadap caregiver burden adalah usia, jenis kelamin, hubungan dengan klien, dan pendidikan; penyakit kronik klien; tingkat ketergantungan fungsional klien yaitu Activity Daily Living (ADL) dan Instrumemtal Activity Daily Living (IADL), lamanya caregiver merawat klien; dan penyakit kronik caregiver.

Michon, et al. (2005) juga mengemukakan bahwa burden ditentukan oleh kekuatan hubungan antara klien dan caregiver. Variabel klien yaitu kebutuhan untuk mengelola perilaku dan gejala psikososial, sedangkan variabel caregiver adalah kepuasan dalam merawat, karakteristik demografi, dan peran sosial. Beban merawat antara lain terkait dengan; masalah fisik yaitu mencakup kelelahan, gangguan tidur, kondisi kronik (hipertensi, arthritis); masalah psikologis antara lain mencakup perasaan cemas, khawatir, pesimis, malu, rasa bersalah, gangguan harga diri, dan depresi; masalah sosial mencakup keterbatasan dalam hubungan dengan orang lain, keterbatasan aktifitas sosial serta waktu luang; masalah finansial mencakup keterbatasan biaya dan sumber finansial (Harris, 2008). Oleh karena itu,

Tabel 1. Karakteristik Keluarga

\begin{tabular}{lcc}
\hline \multicolumn{1}{c}{ Karakteristik keluarga } & Frekuensi (n=205) & Persen (\%) \\
\hline Usia & 142 & 69,3 \\
a. Dewasa (21-44) & 63 & 30,7 \\
b. Pra-lansia (45-59) & & 20,0 \\
Jenis kelamin & 164 & 80,0 \\
a. Laki-laki & & \\
b. Perempuan & 161 & 78,5 \\
Status kawin & 28 & 13,7 \\
a. Menikah & 16 & 7,8 \\
b. Tidak menikah & & \\
c. Janda/duda & 24 & 11,7 \\
Pendidikan & 125 & 60,9 \\
a. Rendah & 56 & 29,4 \\
b. Menengah & & \\
c. Tinggi & 99 & 48,3 \\
Pekerjaan & 106 & 51,7 \\
a. Bekerja & & \\
b. Tidak bekerja & 82 & 40 \\
Penghasilan & 123 & 60 \\
a. Diatas UMR & & \\
b. Dibawah UMR & 52 & 25,4 \\
Hubungan dengan lansia & 153 & 74,6 \\
a. Keluarga inti & & \\
b. Keluarga besar & & \\
\hline
\end{tabular}


dilakukan penelitian untuk memperoleh gambaran tentang faktor-faktor yang berhubungan dengan beban keluarga merawat lansia.

\section{Metode}

Penelitian ini menggunakan desain deskriptif korelasi dengan pendekatan cross sectional. Sampel berjumlah 205 responden yang diambil secara cluster multistage sampling. Lokasi penelitian di beberapa kelurahan di wilayah Jakarta Timur. Variabel independen meliputi karakteristik keluarga, status kesehatan, kemampuan keluarga, dukungan sosial, kepuasan keluarga, dan status fungsional lansia. Sedangkan variabel dependennya beban keluarga merawat lansia. Data dianalisis dengan cara bertahap, mulai dari univariat, bivariat menggunakan uji Chi-square, dan multivariat menggunakan uji regresi logistik.

\section{Hasil}

Lansia sebagai responden dalam penelitian ini sebagian besar berusia antara 60 sampai 74 tahun sebanyak $78,5 \%$, berjenis kelamin perempuan $62 \%$, berstatus janda/ duda 57,6\%, berpendidikan rendah $68,3 \%$, dan tidak bekerja $65,4 \%$. Karakteristik keluarga yang merawat lansia sebagian besar usia antara 21 sampai 44 tahun yaitu 69,3\%, berjenis kelamin perempuan sebesar $80 \%$, menikah $78,5 \%$, pendidikannya menengah $60,9 \%$, tidak bekerja $51,7 \%$, penghasilannya di bawah UMR $60 \%$, dan merupakan keluarga besar 74,6\% (Tabel 1).

Pada tabel 2 menunjukkan bahwa lebih dari 50\% keluarga mengalami beban tinggi dalam merawat lansia. Sedang 48,8\% keluarga mengalami beban yang rendah dalam merawat lansia.

Tabel 2. Beban Merawat Lansia

\begin{tabular}{lcc}
\hline \multicolumn{1}{c}{ Beban Merawat } & Frekuensi & Persen (\%) \\
\hline Rendah & 100 & 48,8 \\
Tinggi & 105 & 52,2 \\
Jumlah & 205 & 100 \\
\hline
\end{tabular}

Tabel 3 menunjukkan bahwa sebagian besar status kesehatan keluarga dalam kondisi sehat $(61,5 \%)$, pengetahuan, sikap, dan keterampilannya baik dalam merawat lansia, merasa puas dalam merawat (51,2\%), dukungan sosial memadai $(51,2 \%)$, dan status fungsional lansianya (Basic Activities of Daily Living (BADL) dan Instrumental Activities of Daily Living $(I A D L))$ sebagian besar adalah mandiri $(77,1 \%$ dan $51,7 \%)$.

Pada tabel 4 menunjukkan bahwa tidak terdapat hubungan bermakna antara karakteristik keluarga yaitu usia, jenis kelamin, status kawin, pendidikan, pekerjaan, penghasilan, dan hubungan keluarga dengan beban keluarga yang merawat lansia. Pada tabel 5 dapat disimpulkan bahwa status kesehatan, kemampuan dalam merawat, dan kepuasan dalam merawat berhubungan secara bermakna dengan beban keluarga yang merawat lansia $(p=0,009$; $p=0,041 ; p=0,021 ; \alpha=0,05)$.

Tabel 6 menunjukkan bahwa Odds Ratio $(O R)$ dari variabel status kesehatan keluarga adalah 2,6. Hal ini artinya keluarga yang kurang sehat akan memiliki beban yang tinggi dalam merawat lansia sebesar tiga kali lebih tinggi dibandingkan dengan keluarga yang sehat setelah dikontrol variabel usia, pengetahuan, dan kepuasan keluarga. Variabel status kesehatan mempunyai kontribusi paling besar terhadap beban keluarga dalam merawat lansia.

\section{Pembahasan}

Hasil penelitian menunjukkan 52,2\% keluarga mengalami beban tinggi dalam merawat lansia (tabel 2). Beban merawat merupakan respon multidimensi terhadap stresor fisik, psikologis, sosial, dan finansial yang dihubungkan dengan pengalaman keluarga dalam merawat klien (Kazuya, Polgar-Bailey, \& Takeuchi, 2000 dalam Etters, Goodall, \& Harrison, 2008). Morimoto, Schreiner, dan Asano (2003) menggambarkan bahwa meningkatnya beban berhubungan secara signifikan terhadap kualitas hidup yang rendah khususnya kesehatan mental keluarga. 
Tabel 3. Distribusi Status Kesehatan Keluarga, Kemampuan Merawat, Kepuasan Kerawat, Dukungan Sosial, dan Status Fungsional Lansia

\begin{tabular}{|c|c|c|}
\hline Variabel & Frekuensi $(n=205)$ & Persen (\%) \\
\hline \multicolumn{3}{|l|}{ Status kesehatan keluarga } \\
\hline Sehat & 126 & 61,5 \\
\hline Kurang sehat & 79 & 38,5 \\
\hline \multicolumn{3}{|l|}{ Kemampuan merawat } \\
\hline \multicolumn{3}{|l|}{ Pengetahuan } \\
\hline a. Baik & 107 & 52,2 \\
\hline b. Kurang & 98 & 47,8 \\
\hline \multicolumn{3}{|l|}{ Sikap } \\
\hline a. Baik & 106 & 51,7 \\
\hline b. Kurang & 99 & 48,3 \\
\hline \multicolumn{3}{|l|}{ Keterampilan } \\
\hline a. Baik & 103 & 50,2 \\
\hline b. Kurang & 102 & 49,8 \\
\hline \multicolumn{3}{|l|}{ Kepuasan merawat } \\
\hline Puas & 105 & 51,2 \\
\hline Kurang puas & 100 & 48,8 \\
\hline \multicolumn{3}{|l|}{ Dukungan sosial } \\
\hline Memadai & 105 & 51,2 \\
\hline Kurang memadai & 100 & 48,8 \\
\hline \multicolumn{3}{|l|}{ Status fungsional lan sia } \\
\hline \multicolumn{3}{|l|}{ BADL } \\
\hline a. Mandiri & 158 & 77,1 \\
\hline b. Bantuan & 47 & 22,9 \\
\hline \multicolumn{3}{|l|}{ IADL } \\
\hline a. Mandiri & 106 & 51,7 \\
\hline b. Bantuan & 99 & 48,3 \\
\hline
\end{tabular}

Berdasarkan hasil studi fenomenologi yang telah dilakukan oleh Asniar (2007), menemukan bahwa keluarga mengalami beban tinggi dalam merawat lansia yaitu beban psikologis yang diidentifikasi melalui karakteristik verbal seperti stres, menangis, dan juga rasa bersalah karena harus meninggalkan klien untuk mencari nafkah, serta perubahan emosi klien yang sering marah dan berperilaku buruk. Sedangkan beban fisik dilihat dari ekspresi wajah kelelahan, ungkapan rasa lelah, jenuh dan capek.

Selain itu, kesulitan keluarga dalam merawat klien terutama membagi waktu antara merawat dan peran lainnya, serta beban ekonomi terkait dengan biaya pengobatan klien. Lee (2008) menemukan bahwa beban yang dialami keluarga dalam merawat lansia berhubungan yang bermakna pada tingkat kekerasan yang dialami oleh lansia. Oleh karena itu, peneliti berasumsi bahwa pada keluarga yang mengalami tingkat beban tinggi dalam merawat lansia, lebih besar kemungkinan untuk melakukan tindakan kekerasan pada lansia baik secara fisik maupun verbal.

Berdasarkan hasil penelitian (pada tabel 4) tidak ditemukan adanya hubungan yang bermakna antara karakteristik keluarga dengan beban merawat. Hal ini bertentangan dengan hasil penelitian Morimoto, Schreiner, dan Asano (2003), mengatakan faktorfaktor yang berpengaruh terhadap beban merawat adalah usia, jenis kelamin, hubungan dengan klien, pendidikan, dan lamanya keluarga merawat klien. 
Jika dilihat dari hasil penelitian ditemukan bahwa keluarga yang berusia dewasa, yaitu usia 21-44 tahun, mengalami beban yang lebih tinggi dalam merawat lansia dibandingkan usia pra-lansia, yaitu usia 45-59 tahun. Hal ini menunjukkan bahwa dalam usia 21-44 tahun, kemungkinan keluarga belum mengalami kematangan emosional sehingga keluarga tidak mampu memahami keinginan lansia dan seringkali terjadi konflik dengan lansia.

Hasil penelitian menunjukkan bahwa ada hubungan bermakna antara pengetahuan merawat dengan beban merawat $(p=0,041 ; \alpha=0,05)$ (tabel 5).
Keluarga yang mempunyai pengetahuan kurang tentang cara merawat lansia berpeluang mengalami beban tinggi dalam merawat lansia. Kemampuan kognitif merupakan sifat mental dan karakteristik individu yang dihubungkan dengan kemampuan yang dibutuhkan untuk berpikir dan persepsi, antara lain seperti inteligensia, pengetahuan, pemahaman, kemampuan beradaptasi, dan kemampuan dalam mengontrol diri.

Pengetahuan, kesadaran, pemahaman, informasi spesifik tentang sesuatu didapat melalui pendidikan dan pengalaman merupakan sumber kognitif khas.

Tabel 4. Hubungan Karakteristik Keluarga dengan Beban Merawat Lansia

\begin{tabular}{|c|c|c|c|c|c|c|c|c|}
\hline \multirow{3}{*}{ Variabel } & \multicolumn{4}{|c|}{ Beban merawat } & \multirow{2}{*}{\multicolumn{2}{|c|}{ Total }} & \multirow{3}{*}{$\mathbf{p}$} & \multirow{3}{*}{ OR $(95 \% \mathrm{CI})$} \\
\hline & \multicolumn{2}{|c|}{ Tinggi } & \multicolumn{2}{|c|}{ Rendah } & & & & \\
\hline & n & $\%$ & $\mathbf{n}$ & $\%$ & n & $\%$ & & \\
\hline \multicolumn{9}{|l|}{ Usia } \\
\hline a. 21-44 tahun & 78 & 54,9 & 64 & 45,1 & 142 & 100 & 0,211 & $1,536(0,842-2,800)$ \\
\hline b. 45-59 tahun & 27 & 43,5 & 36 & 56,5 & 63 & 100 & & \\
\hline \multicolumn{9}{|l|}{ Jenis kelamin } \\
\hline a. Laki-laki & 21 & 51,2 & 20 & 48,8 & 41 & 100 & 1,00 & $1,00(0,504-1,983)$ \\
\hline b. Perempuan & 84 & 51,2 & 80 & 48,8 & 164 & 100 & & \\
\hline \multicolumn{9}{|l|}{ Status kawin } \\
\hline a. Menikah & 79 & 49,1 & 82 & 50,9 & 161 & 100 & 0,660 & $1,198(0,536-2,677)$ \\
\hline b. Tidak menikah & 15 & 53,6 & 13 & 46,4 & 28 & 100 & & \\
\hline c. Janda/duda & 11 & 68,8 & 5 & 31,2 & 16 & 100 & 0,142 & $2,284(0,759-6,869)$ \\
\hline \multicolumn{9}{|l|}{ Pendidikan } \\
\hline a. Rendah & 14 & 58,3 & 10 & 41,7 & 24 & 100 & & \\
\hline b. Menengah & 65 & 52,0 & 60 & 48,0 & 125 & 100 & 0,669 & $1,219(0,491-3,208)$ \\
\hline c. Tinggi & 26 & 46,4 & 30 & 53,6 & 56 & 100 & 0,519 & $1,385(0,515-3,726)$ \\
\hline \multicolumn{9}{|l|}{ Pekerjaan } \\
\hline a. Bekerja & 48 & 48,5 & 51 & 51,5 & 99 & 100 & 0,537 & $0,809(0,467-1,401)$ \\
\hline b. Tidak bekerja & 57 & 53,8 & 49 & 46,2 & 106 & 100 & & \\
\hline \multicolumn{9}{|l|}{ Penghasilan } \\
\hline a. Di atas UMR & 38 & 46,3 & 44 & 53,7 & 82 & 100 & 0,318 & $0,722(0,412-1,265)$ \\
\hline b. Di bawah UMR & 67 & 54,5 & 56 & 45,5 & 123 & 100 & & \\
\hline \multicolumn{9}{|c|}{ Hubungan keluarga dengan lansia } \\
\hline a. Keluarga besar & 75 & 49 & 78 & 51,0 & 153 & 100 & 0,419 & $0,729(0,385-1,381)$ \\
\hline b. Keluarga inti & 30 & 57,7 & 22 & 42,3 & 52 & 100 & & \\
\hline
\end{tabular}


Hal ini sejalan dengan pendapat Notoatmodjo (2003), menyatakan pengetahuan menimbulkan kesadaran yang akhirnya menyebabkan orang berperilaku sesuai pengetahuan yang dimiliki.

Pendidikan kesehatan penting diberikan kepada keluarga dengan tujuan untuk memberdayakan keluarga dan meningkatkan rasa percaya diri serta kompetensi keluarga dalam merawat lansia. Dengan meningkatnya pengetahuan maka akan mengurangi stres merawat lansia (Lueckenotte,
2000). Hasil penelitian oleh Andren dan Elmstahl (2008), yang menggambarkan bahwa intervensi psikoedukasi yang diberikan pada keluarga dapat mengurangi depresi, mengurangi beban merawat, dan meningkatkan pengetahuan keluarga.

Hasil penelitian ini menunjukkan bahwa terdapat hubungan bermakna antara kepuasan dengan beban merawat $(p=0,021 ; \alpha=0,05)$ (tabel 5). Hal ini menunjukkan meningkat kemampuan keluarga merawat lansia maka kepuasan akan meningkat.

Tabel 5. Hubungan Status Kesehatan Keluarga, Kemampuan Merawat, Kepuasan Merawat, Dukungan Sosial, dan Status Fungsional Lansia dengan Beban Merawat Lansia

\begin{tabular}{|c|c|c|c|c|c|c|c|c|}
\hline \multirow{3}{*}{ Variabel } & \multicolumn{4}{|c|}{ Beban merawat } & \multirow{2}{*}{\multicolumn{2}{|c|}{ Total }} & \multirow{3}{*}{$\mathbf{p}$} & \multirow{3}{*}{ OR $(95 \%$ CI $)$} \\
\hline & \multicolumn{2}{|c|}{ Tinggi } & \multicolumn{2}{|c|}{ Rendah } & & & & \\
\hline & $\mathbf{n}$ & $\%$ & $n$ & $\%$ & $\mathbf{N}$ & $\%$ & & \\
\hline \multicolumn{9}{|l|}{ Status keseh atan } \\
\hline Kurang Sehat & 50 & 63,34 & 29 & 36,75 & 79 & 100 & 0,009 & $2,449(1,252-3,300)$ \\
\hline Sehat & 55 & 3,7 & 71 & 6,3 & 126 & 100 & & \\
\hline \multicolumn{9}{|c|}{ Kemampu an merawat } \\
\hline \multicolumn{9}{|c|}{ Pengetahuan } \\
\hline a. Kurang baik & 58 & 59,24 & 40 & 40,85 & 98 & 100 & 0,041 & $1,540(1,252-4,800)$ \\
\hline b. Baik & 47 & 3,9 & 60 & 6,1 & 107 & 100 & & \\
\hline \multicolumn{9}{|l|}{ Sikap } \\
\hline a. Kurang & 55 & 55,64 & 44 & 44,45 & 99 & 100 & 0,289 & $0,714(0,412-1,238)$ \\
\hline b. Baik & 50 & 7,2 & 56 & 2,8 & 106 & 100 & & \\
\hline \multicolumn{9}{|l|}{ Keterampilan } \\
\hline a. Kurang & 57 & 55,94 & 45 & 44,15 & 10210 & 100 & 0,234 & $0,689(0,397-1,194)$ \\
\hline b. Baik & 48 & 6,6 & 55 & 3,4 & 3 & 100 & & \\
\hline \multicolumn{9}{|l|}{ Kepuasan merawat } \\
\hline Tidak Puas & 60 & 60 & 40 & 40 & 105 & 100 & 0,021 & $1,500(1,287-3,872)$ \\
\hline Puas & 45 & 42,9 & 60 & 57,1 & 100 & 100 & & \\
\hline \multicolumn{9}{|l|}{ Dukungan sosial } \\
\hline Kurang Memadai & 58 & 58,04 & 42 & 42,05 & 10010 & 100 & 0,050 & $0,587(0,338-2,020)$ \\
\hline Memadai & 47 & 4,8 & 58 & 5,2 & 5 & 100 & & \\
\hline \multicolumn{9}{|c|}{ Status fungsional lansia } \\
\hline \multicolumn{9}{|c|}{ BADL } \\
\hline a. Bantuan & 30 & 63,84 & 17 & 36,25 & 47 & 100 & 0,049 & $1,512(1,262-3,003)$ \\
\hline b. Mandiri & 75 & 7,5 & 83 & 2,5 & 158 & 100 & & \\
\hline \multicolumn{9}{|l|}{ IADL } \\
\hline a. Bantuan & 57 & 57,64 & 42 & 52,45 & 99 & 100 & 0,047 & $1,610(0,351-3,059)$ \\
\hline b. Mandiri & 48 & 5,3 & 58 & 4,7 & 106 & 100 & & \\
\hline
\end{tabular}


Kepuasan keluarga diukur dengan sikap keluarga dalam merawat meliputi kebersamaan, penerimaan tugas dalam merawat, serta fungsi interpersonal antara lain mencakup dukungan sosial dan kepuasan dalam rumah tangga. Menurut Sales (2003) bahwa pengalaman positif dalam merawat klien dengan penyakit kronis yaitu adanya hubungan timbal balik, kepuasan, menemukan arti merawat. Sedangkan pengalaman negatif adalah ketidakpuasan, stres, depresi, dan konflik dalam keluarga klien.

Merawat lansia di lingkungan keluarga dapat meningkatkan ikatan emosional diantara anggota keluarga. Hasil penelitian yang dilakukan oleh Resnayati, Riasmini, dan Maryam (2010), yaitu melalui studi kualitatif pada keluarga, yang menemukan bahwa keluarga merasa senang dan puas dalam merawat lansia yang merupakan bentuk tanggung jawab serta pengabdian anak kepada orangtua, disamping dapat memberikan perawatan dengan baik, memberikan kasih sayang dan perhatian. Tentunya dalam kondisi tersebut akan mengurangi beban keluarga dalam merawat lansia.

Hasil penelitian ini menunjukkan bahwa terdapat hubungan yang bermakna antara status kesehatan keluarga dengan beban merawat $(p=0,009 ; \alpha=0,05)$ (tabel 5). Hasil analisis multivariat (pada tabel 6) diperoleh Odds Ratio (OR) dari status kesehatan keluarga yaitu 2,6. Hal tersebut artinya keluarga yang kurang sehat akan memiliki beban yang tinggi dalam merawat lansia sebesar 3 kali lebih tinggi dibandingkan dengan keluarga yang sehat setelah dikontrol variabel usia, pengetahuan, dan kepuasan keluarga.
Berdasarkan keempat variabel tersbut, pada nilai $O R$, ditemukan bahwa variabel status kesehatan keluarga mempunyai kontribusi paling besar terhadap beban keluarga dalam merawat lansia. Keluarga yang kurang sehat berpeluang lebih besar mengalami beban yang tinggi dalam merawat lansia dibandingkan dengan keluarga yang sehat. Hal tersebut kemungkinan disebabkan oleh kondisi fisik dan mental yang lelah pada saat sakit atau menderita penyakit sehingga perlu istirahat untuk memulihkan kondisi kesehatannya. Jika dalam kondisi sakit, keluarga diwajibkan untuk merawat lansia maka tentunya akan merasa bersalah atau terbebani.

Hasil penelitian yang dilakukan oleh Sahar (2002), yang memaparkan bahwa keluarga yang merawat lansia pada umumnya mengalami lebih dari satu masalah kesehatan. Dampak dari perawatan yang berhubungan dengan beban merawat ditemukan bahwa nilai rata-rata beban subjektif lebih tinggi dibandingkan dengan beban objektif. Morimoto, Schreiner, dan Asano (2003) mengatakan bahwa penyakit kronik yang dialami oleh keluarga yaitu berhubungan dengan beban merawat klien.

\section{Kesimpulan}

Hasil penelitian ini menunjukkan bahwa terdapat hubungan yang bermakna antara status kesehatan, pengetahuan, kepuasan merawat, dukungan sosial keluarga, dan status fungsional lansia dengan beban keluarga dalam merawat lansia. Keluarga yang kurang sehat berpeluang tiga kali lebih besar mengalami beban yang tinggi dalam merawat lansia dibandingkan dengan keluarga yang sehat.

Tabel 6. Model Akhir Regresi Logistik Variabel yang Berhubungan dengan Beban Merawat Lansia

\begin{tabular}{lccccc}
\hline \multicolumn{1}{c}{ Variabel } & B & Wald & p & OR & $\mathbf{9 5 \%} \boldsymbol{C I}$ \\
\hline Usia keluarga & 0,608 & 3,487 & 0,052 & 1,838 & $0,970-3,480$ \\
Status kesehatan & 0,803 & 6,926 & 0,018 & 2,632 & $1,227-4,059$ \\
Pengetahuan & 0,568 & 3,642 & 0,046 & 1,567 & $1,313-4,015$ \\
Kepuasan & 0,633 & 4,558 & 0,033 & 1,631 & $1,297-3,949$ \\
Constant & 0,065 & 0,035 & 0,152 & & \\
\hline
\end{tabular}


Oleh karena itu, diharapkan bagi pihak Puskesmas dapat mengembangkan program pemberdayaan keluarga melalui pelatihan cara mendeteksi dini beban yang dialami keluarga, cara meningkatkan kesehatan keluarga dan cara perawatan lansia di rumah serta promosi kesehatan untuk mencegah kekerasan dan penelantaran pada lansia (MS, JS, HR).

\section{Referensi}

Andren, S., \& Elmstahl, S. (2008). Psychosocial intervention for family caregivers of people with dementia reduces caregiver's burden: Development and effect after 6 and 12 months. Scan J Caring, 22, 98-109.

Asniar. (2007). Studi fenomenologi tentang pengalaman keluarga merawat anggota keluarga paska stroke di rumah di Kelurahan Depok, Kecamatan Pancoran Mas, Kota Depok Jawa Barat (Tesis master, tidak dipublikasikan). Universitas Indonesia, Jakarta.

Etters, L., Goodall, D., \& Harrison, B.E. (2008). Caregiver burden among dementia patient caregiver: A review of the literature. Journal of the American Academy of Nurse Practitioners, 20, 423-428.

Harris, G.J. (2008). Caregiver Well-being: Factor influencing positive outcomes in the informal caregiving process (Disertation, Doctor of Philosophy). Department of Family and Child Science, Florida State University.
Lee, M. (2008). Caregiver stress and elder abuse among korean family caregiver of elder adult with disabilities. Original Article. J Fame Vio, 23, 702-712.

Lueckenotte, A.G. (2000). Gerontologic nursing (2nd Ed.). St. Louis, Missouri: Mosby, Inc.

Michon, A., Weber, K., Richard-Thomazic, V., \& Giannaropoulos, P., (2005). Dynamic process of family burden in dementia caregiving: A new field for psychotherapeutic intervention. Journal of Japanese psycogeriatric society, 5 (2), 48-54.

Morimoto, T., Schreiner, A.S., \& Asano, H. (2003). Caregiver burden and health related quality of life among Japanese stroke caregiver. Age and aging, 32 (2), 218-223.

Notoatmodjo. (2003). Pendidikan dan perilaku kesehatan. Jakarta: Rineka Cipta.

Resnayati, Y., Riasmini, M., \& Maryam. (2010). Pengalaman keluarga dan petugas kesehatan dalam perawatan lanjut usia di wilayah DKI Jakarta. Jurnal Madya, 10 (1), 44-54.

Sahar, J. (2002). Supporting family carers in caring for older people in the community in Indonesia. (Disertasi, Queensland University of Technology). Centre for Nursing Research, School of Nursing Queensland University of Technology.

Sales, E. (2003). Family burden and quality of life. Quality of life research, 12, 33-41. 